\title{
Research on the practice teaching system of integration of "Teaching, learning and Practicing" in higher vocational computer network security management
}

\author{
ZhuXiongJun \\ Computer Science Department \\ Wuhan Polytechnic \\ Wuhan,China \\ zhuxiongjun@126.com
}

\author{
HanNing \\ Humanities School \\ Wuhan Polytechnic \\ Wuhan, China \\ hanning@163.com
}

\begin{abstract}
The practice teaching which cultivates students' professional ability is a distinguished characteristic of higher vocational education. This research focuses on two aspects of network security -- "attack" and "prevention". Hoping to realize the goal of higher vocational education, it explains how to build this teaching system consisting three parts: the basic ability, professional ability and engineering ability, based on the high quality of skilled personnel training in the integration of "Teaching, learning and Practicing" in higher vocational computer network security management.
\end{abstract}

Keywords-Higher vocational education; Network security; Practice teaching system; Teaching; Integration

\section{INTRODUCTION}

The goal of higher vocational education is to produce high-quality skilled talents who can adapt to the first-line of production, management and service. The vocational education practice teaching system is the core of higher vocational education. Practice teaching in higher vocational colleges and universities plays a very important role, it is not only a verification of the theory as well as the result of students' hard work, more important, it enhances students' professional ability, inspire students' innovative thinking through the process of imitating ,organizing and digesting until they are capable of self-analysis and completing the whole process of practice.

The teaching mode of integration is to make training lab the classroom.Teachers are able to teach while students practice what they just learnt. It helps mingle theory learning with practice process which perfectly demonstrate sensorial experience and abstract thinking at the same time.This mode will be more effective in combining class teaching with job reality.Emphasizing on students' ability to practice and cultivating professional skills can largely improve their professional quality.

With the popularization of Internet application, network security incident has become the lingering shadow in the application of network.

During the past year, Trustwave SpiderLabs investigated more than 300 breaches and performed more than 2,000 penetration tests around the world. Customer records remained a valuable target for attackers,making up 89\% of breached data investigated. Analysis found that attackers had an average of 173.5 days within the victim's environment before detection occurred. [1]
Therefore, the construction of practice teaching system of integration of "Teaching, learning and Practicing" in higher vocational computer network security management, aiming at the ability improvement, will be a quick and effective way for network security management talents to enter the enterprises.

\section{THE CULTIVATION ORIENTATION OF HIGHER VOCATIONAL COMPUTER NETWORK SECURITY MANAGEMENT TALENTS}

To develop talents who cater the needs of society, we have to clarify the type of talents, from a macroscopic point of view, talents can be divided into two categories [2] :

- Academic type talent: they discover and study the objective law.

- Applied talents: they use the objective laws for direct interest for society (social benefits).

According to the level on which the applied talents can turn their academic research into social production ability. They are divided into three categories:

- Engineering talent: engaged in project design, planning and operation planning, etc.

- Technology talents: between engineering talents and skilled talents. They are always in the technical or management position.

- Skilled talents: engaged in specific social production practice, they are always in the first-line production, construction, service and so forth.

From < The ministry of education's advice on vocational colleges' trial of work-integrated learning, work-study program> "(faculty into [2006] no. 4) <The ministry of education's several advices on improving the teaching quality of higher vocational education" (teach high [2006] no. 16 article) which are issued by the ministry of education, we can the essence of higher vocational education of highquality skilled talent is the employment education.

From the social classification of talents, professional post technical requirements and higher vocational training target, vocational network security management talents are prepared for following aspects: first of all, be familiar with network security management method and process;secondly, mastering general hacker-prevention technology and antivirus technology; thirdly, grasping the mainstream operating system security mechanism. Meanwhile, they must be 
equipped with the ability of information analysis and implementation, and the ability to obtain corresponding professional qualification certificate of high-quality skilled talents.

\section{THE RESEARCH ON THE PRACTICE TEACHING SYSTEM OF INTEGRATION OF “TEACHING, LEARNING AND}

PRACTICING” IN HIGHER VOCATIONAL COMPUTER NETWORK SECURITY MANAGEMENT

In the traditional higher education mode, students are used to perform experiments and practice after learning the theoretical knowledge, the lapse in time and space will naturally affect the quality of personnel training. Higher vocational education's theory teaching and practice teaching must be mutually combined and penetrated. How to implement the basic theory teaching to prepare students with "must" and "enough" knowledge and the practice teaching with "must" and "practical" experience? The integration of "Teaching, learning and Practicing" is the only feasible method.

\section{A. The construction of practice teaehing system in network security management}

The ability to carry out computer theory in the application of specific performance is the actual operation ability. Therefore, the practice teaching of the professional personnel training is of particular importance in developing talents. Through market research, and discussion with enterprise experts, in the view of the characteristics of different professional positions, based on the professional knowledge, professional post ability and professional quality structure requirements, the practical ability is divided into three levels: basic ability, professional ability and engineering ability.

Basic ability is the essential skills and basic literacy of practitioners. It is always acquired through experiment, deepening the understanding and then mastery.

Professional ability is a necessity for practitioners who are engaged in specific professional posts in professional work. It is gained through training, strengthening the understanding and then mastery.

Engineering ability is practitioners' problem-solving ability in practical work, it is gained through practice, repetition and finally mastery.

The professional ability in network security management is based on "attack" and "prevention". Practice teaching system is designed to put into use "how to attack" and "how to prevent". Weaving the practice of basic skills, professional ability and engineering practice ability together so as to construct the practice teaching system of higher vocational computer network security management, and using systematic practice-oriented teaching to improve students' practical ability.
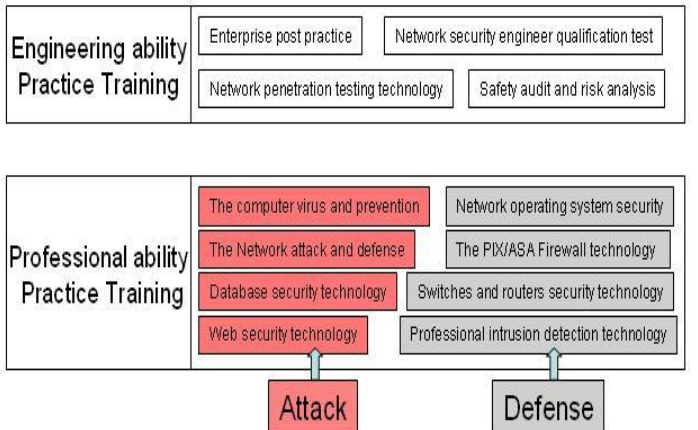

\begin{tabular}{|c|c|c|}
\hline \multirow{3}{*}{$\begin{array}{c}\text { Basic ability } \\
\text { Practice Training }\end{array}$} & Network security foundation & The Principle of Microcomputer \\
\hline & Foundation of computer network & Computer Assembly and Maintenance \\
\hline & The Basics of Computer Application & The C Program Language Design \\
\hline
\end{tabular}

Figure1. The Integration of Teaching,Learning and Doing PracticeTeaching System

B. The establishment of lab for integrating "Teaching, Learning and Practicing” in higher vocational computer network security management

Constructing an internet environment in the lab with switches, routers, and firewall equipments and combining with virtual machine technology is an important teaching approach in the teaching of computer network security management, which helps students to enhance their professional skills, acquire career recognition as well as nurture their professional sensibility.

According to the scale of students at the same time in the room, the 48 of them will be distributed to 6 training platforms, each training platform including eight PCs, a switch, a router, independent of local area network (LAN). The routers will form the Internet environment, and complete network equipment configuration management, server configuration management, network security equipment configuration management.

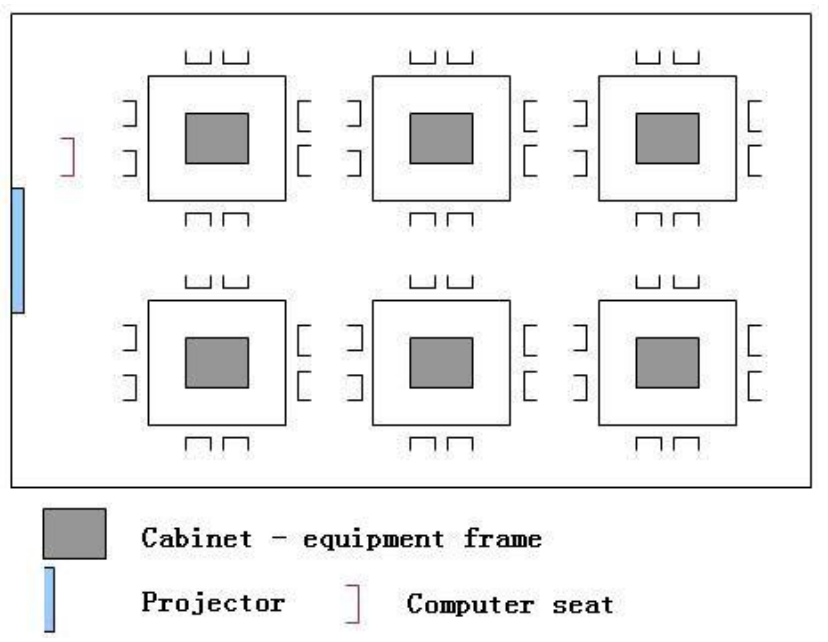

Figure2. The Integration of Teaching,Learning and Doing Laboratory 
Through the virtual machine technology, the system builds a virtual network, carrying out complete network attacks, computer virus, doing host safety, field control management experiment.

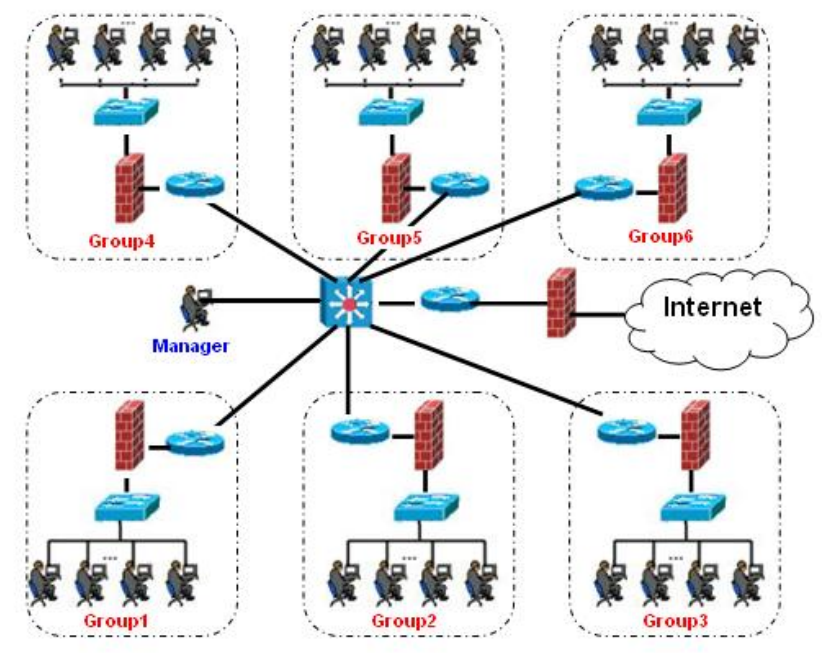

Figure3. The Laboratory Network Topology Structure

Considering of the destructiveness of a lot of information security incidents, experiment environment will be introduced with enterprise information security solutions, such as Beijing Tianma, Potevio, and other security products and experiment instruction so as to complete network attack technology experiment [3].

\section{CONCLUSION}

"It takes ten years to grow trees, but a hundred to develop people." Whether a method, a system is able to solve higher vocational computer professional personnel training process problems remains to be further studied and discussed. In this paper, it only takes the talent training in school of computer and network security management in Wuhan Polytechnic College as an example, the construction of practice teaching system is to provide reference for the development of highquality skilled personnel of higher vocational computer network technology professional service.

\section{ACKNOWLEDGMENT}

This paper is a Chinese electronic education to higher vocational computer kind professional 2012 annual planning task "computer network technology professional network security management direction to do teaching practice teaching system integration project of the study of one of a series of achievements, subject Numbers: CESEZ2012-15. This study has already been used wuhan vocational and technical college computer network technology professional network security management direction talent cultivation, the effect of the emerging.

\section{REFERENCES}

[1] The Trustwave 2012 Global Security Report. http://www.trustwave.com/gsr

[2] ZHOUHong,DENGRiCheng,Research on the Evaluation of Application Oriented Reesonnel in China(Ch), http://www.china.com.cn/news/zhuanti/09rcbg/200909/21/content_18568744_4.htm

[3] Teaching Plan Of Information Security, Beijing zhengyang tianma information technology Co., LTD,2012,6

[4] SimpleNAD Network attack experiment teaching system , http://www.simpleware.com.cn/productinfo/11/74

[5] The network information safety experimental teaching system, http://www.jlcss.com.cn/jlcss/teaching_nis.html 